\title{
Biological potential of Citharexylum myrianthum Cham. leaves in vitro and phenolic profile by HPLC-ESI-MS/MS
}

\author{
Adrielli Tenfen ${ }^{* 1}$, Camile Cecconi Cechinel-Zanchett ${ }^{1}$, Ana Paula Dalmagro' ${ }^{1}$, Priscila Zimath ${ }^{1}$, Ariela Maína \\ Boeder $^{2}$, Gabriel M. D. Santos ${ }^{1}$, Adriana Campos ${ }^{1}$, Diogo Alexandre Sibert ${ }^{3}$, Gustavo Micke ${ }^{3}$, Luciano Vitali ${ }^{3}$, \\ Caio Maurício Mendes de Córdova ${ }^{2}$, Alexandre Bella-Cruz ${ }^{1}$, Rivaldo Niero ${ }^{1}$, Valdir Cechinel-Filho ${ }^{1}$ \\ ${ }^{1}$ Programa de Pós-graduação em Ciências Farmacêuticas, Núcleo de Investigações Químico-Farmacêuticas (NIQFAR), Universidade do Vale do Itajaí - \\ UNIVALI, Itajaí, Santa Catarina, Brazil. \\ ${ }^{2}$ Departamento de Ciências Farmacêuticas, Universidade Regional de Blumenau (FURB), Blumenau-SC, Brazil. \\ ${ }^{3}$ Programa de Pós-graduação em Química, Universidade Federal de Santa Catarina (UFSC), Florianópolis-SC, Brazil.
}

\section{ARTICLE INFO \\ Article history: \\ Received on: 17/06/2018 \\ Accepted on: 16/07/2018 \\ Available online: 30/09/2018}

\section{Key words:}

antibacterial, cytotoxicity, medicinal plant,

phytotherapy, phenolic content.

\begin{abstract}
This study aimed to evaluate the antimicrobial, cytotoxic effects in vitro and phenolic profile of Citharexylum myrianthum Cham. leaves. Dried leaves were macerated with methanol and subjected to liquid-liquid partition with solvents of increasing polarity, furnishing the methanolic extract (ME), dichloromethane (DCMF) and ethyl acetate (EAF) fractions. They were subsequently analyzed by HPLC-ESI-MS/MS. Six strains of Mycoplasma, Bacillus subtilis, Escherichia coli, Staphylococcus aureus, and Candida albicans, were used to determine the antimicrobial effects, and minimum inhibitory concentrations (MIC) values of less than $1000 \mu \mathrm{g} \cdot \mathrm{mL}^{-1}$ were considered active. To evaluate the cytotoxic effects, the 3-[4,5-dimethylthiazol-2-yl]-2,5 diphenyl tetrazolium bromide assay (MTT) test was conducted with colorectal adenocarcinoma (HT-29), non-small lung cancer (NCI-H460) and non-cancer fibroblast (MRC5) cell lines. HPLC-ESI-MS/MS analysis identified four main phenolic compounds, vanillic, p-coumaric and salicylic acids and hispidulin. All samples were considered active against Mycoplasmas, mainly against M. hominis, with MIC values of $250 \mu \mathrm{g} \cdot \mathrm{mL}^{-1}$. With respect to cytotoxicity, the ME and DCMF $\left(100 \mu \mathrm{g} \cdot \mathrm{mL}^{-1}\right)$ reduced cell viability by $50 \%$ in both the HT-29 and NCI-H460 cell lines but were non-cytotoxic against the MRC5. These results in vitro showed that C. myrianthum Cham. may be a possible candidate as an antimicrobial and antitumor agent. However, further studies in vivo are needed to confirm its effects.
\end{abstract}

\section{INTRODUCTION}

Medicinal plants are a very promising field for the discovery of new therapeutic agents to treat common and complex diseases (Bosse, 2014). Among public health problems worldwide, bacterial resistance has been one of the greatest obstacles to therapeutic success, being directly related to the reduction in the number of antibiotics available (Michelin et al., 2005; Antunes et al., 2006). Another serious public health problem worldwide is cancer (Abu-Darwish and Efferth, 2018). However, natural compounds have been described in the literature as interesting candidates for the development of new treatments for several

\footnotetext{
"Corresponding Author

Adrielli Tenfen, Ph.D, Universidade do Vale do Itajai - UNIVALI, Itajaí,

Santa Catarina,Brazil.E-mail: cechinel@univali.br
}

ailments, including infection and cancer (Newman and Cragg, 2016).

Citharexylum myrianthum Cham., known as "tucaneira" in Brazil, is a tree with white flowers, commonly used in reforestation and landscaping, and is found in Paraguay, Argentina, and Brazil, especially in the Mata Atlântica, Cerrado and Caatinga biomes (Rocca-de-Andrade, 2001; Amaral et al., 2013). Its wood is also used for medicinal purposes (IPE, 2016). However, studies of $C$. myrianthum Cham. are scarce in the literature. The genus Citharexylum has shown promising biological activities, such as antioxidant and nephroprotector (Khan and Siddique, 2012), antiinflammatory, gastroprotector, hypoglycemic, antipyretic (Hamed et al., 2014; Mohammed et al., 2016), and antibacterial (Mar and Pripdeevech, 2012) activities. Regarding its constituents, different compounds were found, including flavonoids, terpenoids, 
carotenoids, alkaloids, saponines and iridoids (Balázs et al., 2006; Khan and Siddique, 2012; Barizão et al., 2016; Saidi et al., 2018).

The present work aimed to investigate the phenolic profile of $C$. myrianthum Cham. leaves, its effects on bacteria with and without cell walls (mollicutes), and its effects in normal and cancer cell lines.

\section{MATERIAL AND METHODS}

\section{Plant material}

C. myrianthum Cham. (150 g) leaves were collected in Balneário Camboriú (SC, Brazil) in April 2016. It was identified and a voucher under number 56933 was deposited at Barbosa Rodrigues Herbarium (Itajai/SC, Brazil). The leaves were dried and cut into small pieces and extracted by maceration with methanol for seven days at room temperature. After, the solvent was filtered and concentrated in a rotary evaporator under reduced pressure $\left(50^{\circ} \mathrm{C}\right)$ furnishing the methanolic extract $(\mathrm{ME}), 67.2$ g (44.88\%). The ME was partitioned with solvents of different polarities to obtain the respective fractions of dichloromethane (DCMF) and ethyl acetate (EAF), according to previous studies developed by our research group.

The whole process from the collection of the plant material to the extraction of the extract and fractions was carried out strictly observing the conventional phytochemical conditions (granulometry, drying temperature, solvent extraction quality, and solvent evaporation temperature) in order to maintain a control of the material to be tested.

\section{Identification of phenolic compounds by HPLC-LC-ESI- MS/ MS}

The analysis was conducted in an Agilent ${ }^{\circledR} 1200$ chromatograph, with a Phenomenex ${ }^{\circledR}$ Synergi $4 \mu$ Polar-RP 80A column $(150 \mathrm{~mm} \times 2 \mathrm{~mm} \mathrm{ID}$, the particle size of $4 \mu \mathrm{m})$ at a temperature of $30^{\circ} \mathrm{C}$. The eluent was formed by mixing solvents A ( $\mathrm{MeOH}: \mathrm{H}_{2} \mathrm{O}$ in ratio of 95:5, $\left.\mathrm{v} \mathrm{v}^{-1}\right)$ and $\mathrm{B}\left(\mathrm{H}_{2} \mathrm{O}\right.$ :formic acid $0: 1 \%$ ) as follows: $1^{\text {st }}$ stage $-10 \%$ solvent $\mathrm{A}$ and $90 \% \mathrm{~B}$ (isocratic mode) for 5 minutes; $2^{\text {nd }}$ stage - linear gradient of solvents A and B (from 10 to $90 \%$ of $\mathrm{A}$ ) for 2 minutes; $3^{\text {rd }}$ stage $-90 \%$ solvent $\mathrm{A}$ and $10 \%$ $\mathrm{B}$ (isocratic mode) for 3 minutes; $4^{\text {th }}$ stage - linear gradient of solvents A and B (from 90 to $10 \%$ of A) for 7 minutes with a flow rate of $250 \mu \mathrm{L} \mathrm{min}{ }^{-1}$ in the mobile phase. In all the analyses, the injected volume was $5 \mathrm{uL}$.

The liquid chromatograph was coupled to a mass spectrometry system consisting of a hybrid triple quadrupole/linear ion trap mass spectrometer Qtrap ${ }^{\circledR} 3200$ (Applied Biosystems/ MDS SCIEX, USA) with TurboIonSpray ${ }^{\circledR}$ as the ionization source, in negative ionization mode. The source parameters used were: ion spray interface quadrupole at $400^{\circ} \mathrm{C}$; ion spray voltage of 4500 $\mathrm{V}$; curtain gas, 10 psi; nebulizer gas, 45 psi; auxiliary gas, 45 psi; collision gas, medium. The software Analyst $t_{\mathbb{R}}$ (version 1.5.1) was used to record and process the data. Pairs of ions were monitored in Multiple Reaction Monitoring (MRM) mode (Schulz et al., 2015). For the identification of phenolic compounds, 45 standards were dissolved in methanol $\left(1 \mathrm{mg} \mathrm{L}^{-1}\right)$ and analyzed under the same conditions as described above. The respective standards were used for comparation: 4-aminobenzoic acid, 4-hydroxymethylbenzoic acid, 4-methylumbelliferone, apigenin, aromadendrin, caffeic acid, carnosol, catechin, chlorogenic acid, chrysin, cinnamic acid, coniferaldehyde, ellagic acid, epicatechin, eriodictyol, ferulic acid, fustin, galangin, gallic acid, hispudulin, isoquercetin, kaempferol, mandelic acid, methoxyphenylacetic acid, myricetin, naringenin, naringin, $p$-anisic acid, $p$-coumaric acid, pinocembrin, protocatechuic acid, quercetin, resveratrol, rosmarinic acid, rutin, salicylic acid, scopoletin, sinapaldehyde, sinapic acid, syringaldehyde, syringic acid, taxifolin, umbelliferone, vanillic acid and vanillin.

\section{Antimicrobial activity (anti-mollicutes, antibacterial activity with cell wall bacteria and yeast)}

The anti-mollicutes assays were conducted at the Clinical Microbiology Laboratory of FURB, which provided the bacterial strains: Mycoplasma mycoides subsp. capri (NCTC 10137); Mycoplasma genitalium (ATCC 33530), Mycoplasma hominis (ATCC 23114), Mycoplasma subs capricolum (ATCC 27343), Mycoplasma pneumoniae 129 (ATCC 13883), and Mycoplasma pneumoniae FH (ATCC 13883). For the growth of the bacterial strains, Arginine Liquid Medium (MLA) broth was used for $M$. hominis, and SP4 (specific for Mycoplasmas) broth was used for M. mycoides subsp. capri and M. genitalium, M. subs capricolum, M. pneumonia 129 and M. pneumonia FH (Velleca et al., 1979).

Bacteria with cell wall and yeast were also evaluated. The assays were conducted at the Microbiology Laboratory of UNIVALI, which provided the bacterial strains: Staphylococcus aureus (ATCC 25923), Escherichia coli (ATCC 11775), Bacillus subtilis (ATCC 14579) and Escherichia coli (ATCC 11775), and the yeast Candida albicans (ATCC 10231).

The microdilution broth assay was performed in sterile 96-well microplates, as recommended by the Clinical and Laboratory Standards Institute (CLSI, 2012) with some modifications for cell-wall bacteria and yeast, and Bébéar and Robertson (1996) for mollicutes.

The samples were properly prepared and transferred to each microplate well with the appropriate culture medium, in order to obtain a twofold serial dilution of the original extract in a $10 \%$ medium/dimethyl sulfoxide (DMSO) solution, obtaining sample concentrations of between $1000 \mu \mathrm{g} \cdot \mathrm{mL}^{-1}$ to $7.81 \mu \mathrm{g} \cdot \mathrm{mL}^{-1}$. The inoculum containing $10^{4}$ to $10^{5}$ microorganisms per $\mathrm{mL}$ in MLA and SP4 for mollicutes, Mueller-Hinton broth for bacteria and Sabouraud dextrose $2 \%$ broth for yeast, were then added to each well. A number of wells were reserved in each plate to test for sterility control (no inoculum added), positive control (gentamycin or ciprofloxacin to anti-mollicutes activity, ampicillin for antibacterial activity and ketoconazole for antifungal activity) were used. Inoculum viability (no extract added), and the DMSO inhibitory effect, were also used.

The microplates were incubated at $37^{\circ} \mathrm{C} \pm 1^{\circ} \mathrm{C}$ for 24 or 48 hours (depending on the bacterium) and $30^{\circ} \mathrm{C} \pm 1^{\circ} \mathrm{C}$ for 24 hours (yeast). Thereafter, the growth of mollicute strains was detected by observing the color change in the medium and for bacteria and yeast, the turbidity was observed. The MIC was defined as the lowest concentration of the samples able to inhibit microbial growth.

\section{Cell viability}

The cytotoxic effect of methanolic extract and 
dichloromethane fraction of $C$. myrianthum Cham. leaves were analyzed using the 3-[4,5-dimethylthiazol-2-yl]-2,5 diphenyl tetrazolium bromide (MTT) assay with 2 human cancer cell lines: HT-29 (colorectal adenocarcinoma) and NCI-H460 (nonsmall lung cancer cell); and one non-cancer cell line MRC-5 cell line (normal human fibroblasts). The cell lines were obtained by American Type Culture Collection (ATCC). Cells were cultured in Dulbecco's Modified Eagle Medium (DMEM) $\left(\mathrm{Gibco}^{\mathrm{TM}}\right)$ supplemented with $10 \%$ fetal bovine serum and antibiotics (Penicillin:Streptomycin $1.000 \mu \mathrm{g} / \mathrm{L}: 1.000 \mathrm{U} / \mathrm{L}, 1 \mathrm{~mL} . \mathrm{L}^{-1}$ ) at $37^{\circ} \mathrm{C}$ in a humidified atmosphere in the presence of $5 \% \mathrm{CO}_{2}$ and $95 \%$ air. They were plated in 96-well plates in a total volume of $200 \mu \mathrm{L} /$ well containing $1 \times 104$ cells, and cultured overnight. On the following day, an MTT assay was performed on a well plate and was considered the starting point (day 0). In the other plates, the medium was replaced by extracts at concentrations of 10,30 , 50,100 and 300 in quadruplicate. The extracts were diluted in dimethyl sulfoxide $(\mathrm{DMSO})$. Control = medium + DMSO. After $72 \mathrm{~h}$ of treatment, the MTT assay was performed. Each well of the plates was replaced with $110 \mu \mathrm{L}$ of medium containing MTT (5 mg.mL $\mathrm{m}^{-1}$ ) in phosphate-buffered saline (PBS) and incubated for 1 hour. The medium was removed and $500 \mu$ of DMSO was added to each well. The plates were shaken in the dark for 10 minutes to dissolve the MTT-formazan crystals. The absorbance of purple formazan, proportional to the number of viable cells, was measured at $570 \mathrm{~nm}$ using a microplate reader. The results were presented as mean \pm standard deviation in quadruplicate (Seoane et al., 2010). The viability percentage was calculated: cell viability $(\%)=$ sample absorbance $\times 100 /($ control absorbance $)$.

Table 1: Phenolic compounds identified in Citharexylum myrianthum Cham. leaves by HPLC-ESI-MS/MS.

\begin{tabular}{|c|c|c|c|c|c|c|c|c|}
\hline Number & Compounds & Rt* $^{*}$ (min) & Calculated Mass & Experimental mass $[\mathrm{M}-\mathrm{H}]$ & MS/MS $(m / z)$ & ME & DCMF & EAF \\
\hline 1 & Vanillic acid & 9.19 & 168.14 & 162.90 & 119.10 & $\mathrm{X}$ & $\mathrm{X}$ & \\
\hline 2 & $\rho$-coumaric acid & 9.72 & 164.16 & 166.90 & 108.00 & $\mathrm{X}$ & $\mathrm{X}$ & $\mathrm{X}$ \\
\hline 3 & Salycilic acid & 10.58 & 138.12 & 136.85 & 90.11 & $\mathrm{X}$ & $\mathrm{X}$ & \\
\hline 4 & Hispidulin & 11.99 & 300.27 & 298.95 & 284.00 & $\mathrm{X}$ & $\mathrm{X}$ & $\mathrm{X}$ \\
\hline
\end{tabular}

$* \mathrm{Rt}=$ retention time $($ minutes $) ; \mathrm{ME}=$ metanolic extract; $\mathrm{DCMF}=$ Dichloromethane fraction; $\mathrm{EAF}=$ Ethyl acetate fraction.

\section{Statistical analysis}

Statistical analysis was performed with GraphPad PRISM ${ }^{\circledR}$ software, version 5.0, using the analysis of variance (ANOVA) followed by the Bonferroni test. The results were expressed as mean \pm elevated plus maze $(\mathrm{EPM})$ and the differences were considered statistically significant at $\mathrm{p}<0.05$.

\section{RESULTS AND DISCUSSION}

\section{Identification of phenolic compounds by HPLC-LC-ESI- MS/} MS

The phytochemical analysis was carried out by partitioning of C. myrianthum Cham. furnishing 2.83 (4.27\%) and $11.12 \mathrm{~g}(16.87 \%)$ of dichloromethane (DCMF) and ethyl acetate fractions (EAF), respectively. This perceptual difference between fractions may be related to the presence of phenolic compounds evidenced in the by characteristic polar of ethyl acetate fraction compounds. The presence of these compounds was observed by thin layer chromatographic analysis using specific reagents as ferric chloride. In addition, different climatic conditions and seasonality are other factors that can interfere in the phytochemical composition (Gobbo-Neto and Lopes, 2007).

To clarify the chemical profiling of the extract and fractions, they were evaluated by HPLC-ESI-MS/MS, showing the presence of four phenolic compounds, as shown in Table 1.

There are studies that describe the presence of phenolic compounds in the genus Citharexylum, especially on the fruits (Barizão et al., 2016), however, of the 45 compounds evaluated, only 4 phenolic compounds were identified in the extracts and fractions of $C$. myrianthum Cham. leaves. In the crude extract, vanilinic acid [1], $\rho$-coumaric acid [2], salicylic acid [3] and hispidulin [4] were identified (Figure 1). The same four compounds were identified in the DCMF. In the EAF, only $\rho$-coumaric acid and hispidulin were identified, which are characteristic skeletons from the Citharexylum genus.<smiles>COc1cc(C(=O)O)ccc1O</smiles>

$[1]$<smiles>O=C(O)c1ccccc1O</smiles>

$[3]$<smiles>O=C(O)/C=C/c1ccc(O)cc1</smiles>

$[2]$<smiles>COc1c(O)cc2c(c1O)CC=C(c1ccc(O)cc1)O2</smiles>

$[4]$
Fig. 1: The molecular structure of phenolic compounds identified in the leaves of Citharexylum myrianthum Cham.: vanilinic acid [1], $\rho$-coumaric acid [2]; salicylic acid [3] and hispidulin [4].

It is important to mention that this is the first work that identified this compound in the species, C. myrianthum Cham. Also, this is the first time, to our knowledge, that $\rho$-coumaric acid, salicylic acid, and hispidulin were identified in the Citharexylum genus. Only the vanillic acid was already described in the genus by Saidi et al. (2018), which was isolated from the trunk bark ethyl acetate extract of $C$. spinosum $\mathrm{L}$.

Although rare, some species belonging to the Citharexylum genus were previously studied phytochemically. For example, from Citharexylum caudatum fruits different kinds of iridoids were isolated (Ayers and Sneden, 2002). The aerial 
parts of C. spinosum L. showed the presence of iridoid glucosides, such as 7-S,S-O-acetate of lamiide, lamiide, lamiidoside, duranterectoside $\mathrm{C}$, and 8-epiloganin, and one known as lignan glucoside (+)-lyonirenisol-3a- $O$-S,S- $D$-glucopyranoside (Balázs et al., 2006). Khan and Siddique (2012) evaluated the chloroform extract of $C$. spinosum leaves for its chemical composition and observed the presence of flavonoids, terpenoids, alkaloids and very low amounts of saponins.

From the stem bark of $C$. fruticosum, were isolated lupeol and stigmasterol, together with a new compound, identified as (2S)-p-hydroxyphenethyl 2-bromo-2-methyldodeconate and 7,3'-dimethoxy-5,4'-dihydroxy flavone Ganapaty et al. (2010).

\section{Antibacterial activity}

For the interpretation of the tests, the criteria described by Holetz et al. (2002) were used. For Extracts that displayed minimum inhibitory concentrations (MIC) values less than 100 $\mu \mathrm{g} . \mathrm{mL}^{-1}$, the antimicrobial activity was considered high; from 100 to $500 \mu \mathrm{g} \cdot \mathrm{mL}^{-1}$ the antimicrobial activity was moderate; from 500 to $1000 \mu \mathrm{g} \cdot \mathrm{mL}^{-1}$ the antimicrobial activity was weak and over $1000 \mu \mathrm{g} \cdot \mathrm{mL}^{-1}$ the extract was considered inactive.

Mollicutes are the smallest microorganisms capable of self-replication. They are responsible for the development of urogenital and respiratory diseases such as pneumonia, particularly in immunocompromised patients (Muraiana et al., 2009). The fact that these microorganisms do not have a cell wall makes them resistant to all antibiotics with the mechanism of action targeted at them (Murray, 2007). Among the tested samples, the DCMF showed the best results for the anti-mollicute activity, particularly against $M$. hominis; $M$. genitalium with MIC values of $250 \mu \mathrm{g} \cdot \mathrm{mL}^{-1}$. This fraction also showed activity against $M$. capricolum and M. mycoides with MIC values of $500 \mu \mathrm{g} \cdot \mathrm{mL}^{-1}$, revealing moderate activity.

ME also exhibited moderate activity against $M$. hominis $\left(\mathrm{MIC}=250 \mu \mathrm{g} \cdot \mathrm{mL}^{-1}\right) ; M$. capricolum and M. mycoides (MIC $\left.=500 \mu \mathrm{g} \cdot \mathrm{mL}^{-1}\right)$. These results are important because reports on the resistance of moles as fluoroquinolones (the main class of antibiotics used) have increased in recent years (Deguchi et al., 2017). The moderate activity presented in ME and DCMF may be related to the presence of the same phenolic compounds in both samples, especially vanillic and salicylic acid. These compounds have antibacterial activity described in the literature, particularly vanillic acid (Rasheeda et al., 2018). In addition, these compounds are not present in EAF, which showed less activity compared to $\mathrm{ME}$ and DCMF, with MIC values of $1000 \mu \mathrm{g} \cdot \mathrm{mL}^{-1}$ against M. hominis. They showed no activity against other strains of mollicutes tested.

This is the first work to evaluate the anti-mollicute activity of samples with these compounds. It is known that vanillic acid is capable of inhibiting bacterial growth and decreasing bacterial resistance to heat (Yemip et al., 2011). Mycoplasmas are also sensitive to increases in temperature. Thus, if they become more temperature sensitive, their growth may be inhibited. It is important to note that there are probably other compounds in extracts and fractions that are also responsible for the antimollicute activity, and that none of the compounds isolated have been tested in this work. It can be concluded that these compounds inhibit bacterial growth by a different mechanism, which is not related to the bacterial wall.
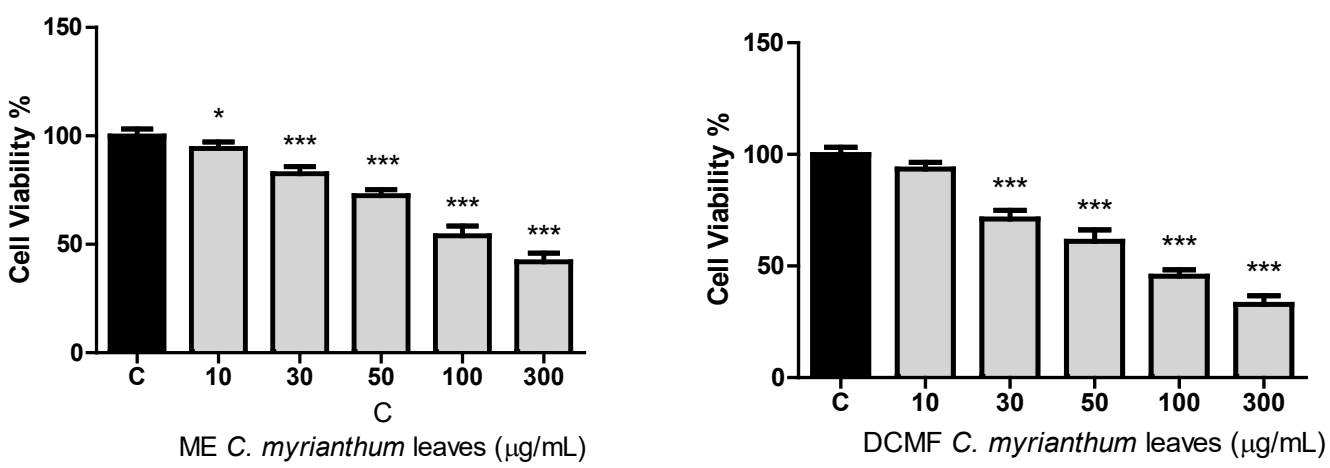

Fig. 2: Cytotoxic effect of methanolic extract (ME) and dichloromethane fraction (DCMF) of C. myrianthum Cham. leaves at different concentrations on HT-29 cells. $\mathrm{C}=$ control (medium $+\mathrm{DMSO}) ; \mathrm{ME}=$ methanolic extract; $\mathrm{DCMF}=$ dichloromethane fraction.

\section{Cytotoxic effect}

Regarding the cytotoxic potential of C. myrianthum Cham. leaves, the ME and DCMF were able to reduce cell viability, presenting effect in the two cancer cells lines used (Figures 2 and 3). The effect was dose-dependent and the concentration of $100 \mu \mathrm{g} \cdot \mathrm{mL}^{-1}$ reduced $50 \%$ of cell viability in both colorectal adenocarcinoma (HT-29) and non-small lung cancer (NCI-H460) cell lines, with the DCMF being more active.

Newman and Cragg (2016) have shown that from the 1940 s to the end of 2014, of the 175 small molecules approved to treat cancer, $49 \%$ were either natural products or directly derived therefrom. Thus, natural products can be an effective and economical alternative, and the use of plant extracts may be important in various therapeutic treatments (Eller et al., 2015).

Some of the phenolic compounds identified in both ME and DCMF have well established antitumor potential, especially hispidulin, which has been described as a potential antitumor agent, with proven efficacy against different types of cancer cell lines, particularly the hepatoma cell line (Bel-7402), with $\mathrm{IC}_{50}$ of 19.8 g.mL $\mathrm{mL}^{-1}$ (Yu et al., 2007). In addition, this compound showed activity against acute myeloid leukemia through mitochondrial apoptosis, by targeting the extracellular matrix metalloproteinase inducer, and in glioblastoma, by activating 5' AMP-activated protein kinase (Wang et al., 2015; Gao et al., 2016). 

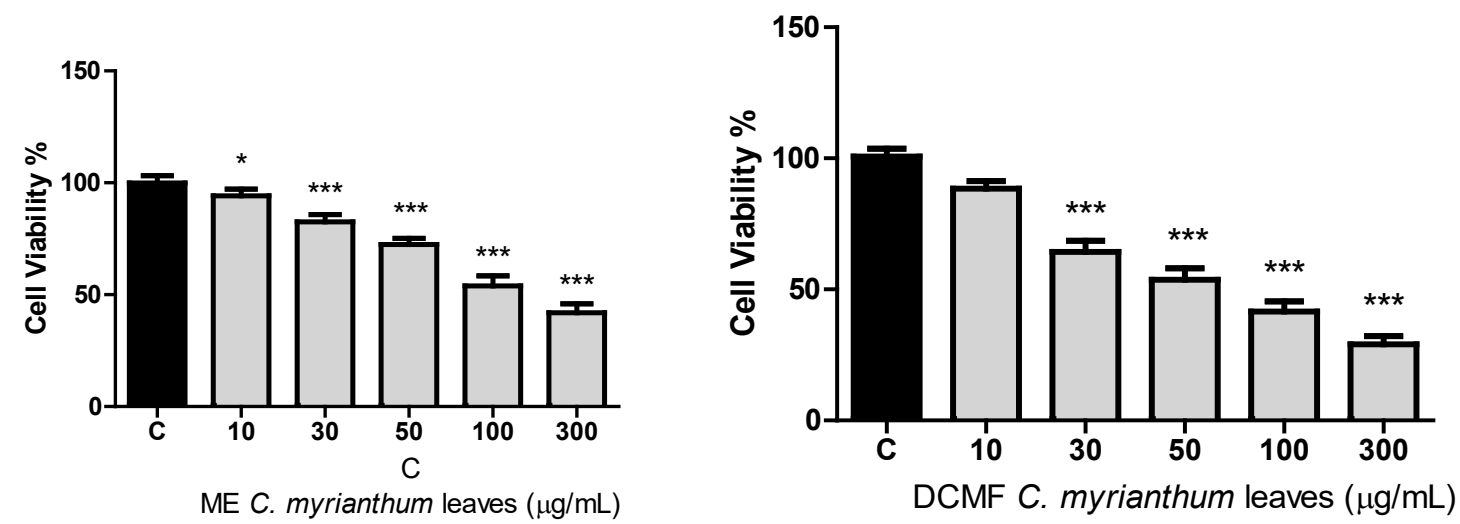

Fig. 3: Cytotoxic effect of methanolic extract (ME) and dichloromethane fraction (DCMF) of C. myrianthum Cham. leaves in different concentrations on NCI-H460 cells. $\mathrm{C}=$ control $($ medium $+\mathrm{DMSO}) ; \mathrm{ME}=$ methanolic extract; $\mathrm{DCMF}=$ dichloromethane fraction.
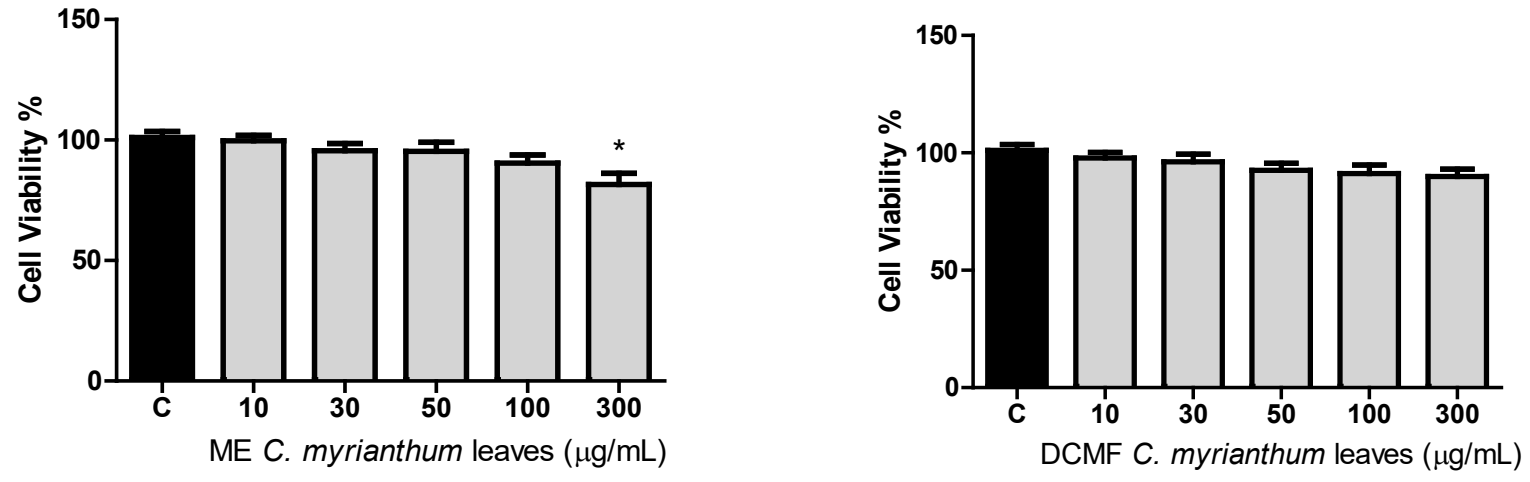

Fig. 4: Cytotoxic effect of methanolic extract (ME) and dichloromethane fraction (DCMF) of C. myrianthum Cham. leaves at concentrations of 10-300 $\mu$ g.mL ${ }^{-1}$ on MRC5 cells. $\mathrm{C}=$ control (medium $+\mathrm{DMSO}$ ); $\mathrm{ME}=$ methanolic extract; $\mathrm{DCMF}=$ dichloromethane fraction.

Another phenolic acid identified in C. myrianthum Cham. leaves were vanillic acid, a compound that is widely used in the food industry to flavor and preserve products. C. myrianthum possesses antioxidant, hepatoprotective, cardioprotective, and antiapoptotic activities, as well as cytotoxicity and antimutagenic effect in Rattus norvegicus hepatoma cells (Almeida et al., 2016) and in the human hepatocellular carcinoma cell line in high concentrations (Intisar et al., 2012). p-coumaric acid has also shown cytotoxic activity against the HT-29 cell line, with the inhibitory growth of $39.4 \%$ (Rosa et al., 2015).

It is important to highlight that this is the first time the cytotoxic effect of $C$. myrianthum Cham. has been demonstrated, and also, the first species of the genus to exert such activity. Another important point to emphasize is that despite the cytotoxic effects on the cancer cell lines tested, both ME and DCMF were non-cytotoxic against the non-cancer fibroblast MRC5 cell line (Figure 4), which demonstrates selective cytotoxicity. Although this is an in vitro study, and experiments in vivo are needed, this is nevertheless an interesting finding, because chemotherapeutic drugs exert cytotoxic and/or cytostatic effects on normal cells, leading to systemic toxicity due to a lack of specificity (Johnstone et al., 2002).
Table 2: Antibacterial activity of extract and fractions obtained from the leaves of C. myrianthum Cham.

\begin{tabular}{ccccc}
\hline \multirow{2}{*}{ Samples } & ME & DCMF & EAF & Positive control \\
\cline { 2 - 5 } & \multicolumn{4}{c}{ MIC $\left(\boldsymbol{\mu g} \cdot \mathbf{m L}^{-1}\right)$} \\
\hline M. hominis & 250 & 250 & 1000 & 2 \\
M. capricolum & 500 & 500 & $>1000$ & 2 \\
M. mycoides & 500 & 500 & $>1000$ & 2 \\
M. pneumoniae $\mathrm{FH}$ & 1000 & 1000 & $>1000$ & 2 \\
M. genitalium & 1000 & 250 & $>1000$ & 2 \\
S. aureus & $>1000$ & $>1000$ & $>1000$ & $\mathrm{nt}$ \\
B. subtilis & $>1000$ & $>1000$ & $>1000$ & $\mathrm{nt}$ \\
E. coli & $>1000$ & $>1000$ & $>1000$ & $\mathrm{nt}$ \\
C. albicans & $>1000$ & $>1000$ & $>1000$ & $\mathrm{nt}$ \\
\hline
\end{tabular}

$\mathrm{nt}=$ not tested.

\section{CONCLUSION}

This study demonstrates the presence of the phenolic compounds vanillic, $\rho$-coumaric and salicylic acids, and hispidulin in C. myrianthum Cham. leaves by HPLC-ESI-MS/MS analysis. 
It is the first time that $\rho$-coumaric and salicylic acids, as well as hispidulin, have been observed in this genus. The methanolic extract and dichloromethane fraction from $C$. myrianthum Cham. leaves also showed antibacterial effects against mollicutes strains, especially against M. hominis. It also demonstrates, for the first time, the selective cytotoxic properties against colorectal adenocarcinoma and non-small lung cancer cell lines. Taken together, these results show that $C$. myrianthum Cham. may have interesting therapeutic potential, therefore it is important to continue research with this species.

\section{ACKNOWLEDGEMENT}

The authors are grateful to Oscar Benigno Iza for the botanical support, and also to the Conselho Nacional de Desenvolvimento Científico e Tecnológico (CNPq), the Coordenação de Aperfeiçoamento de Pessoal de Nível Superior (CAPES), the Fundação de Amparo à Pesquisa e Inovação do Estado de Santa Catarina (FAPESC) and Universidade do Vale do Itajaí-UNIVALI for the financial support.

\section{CONFLICTS OF INTEREST}

There are no conflicts of interest.

\section{REFERENCES}

Abu-Darwish MS, Efferth T. Medicinal plants from near east for cancer therapy. Front Pharmacol, 2018; 31:9-56.

Almeida IV, Cavalcante FM, Vicentini VE. Different responses of vanillic acid, a phenolic compound, in HTC cells: cytotoxicity, antiproliferative activity, and protection from DNA-induced damage. Genet Mol Res, 2016; 15(4).

Amaral WAN, Antiqueira LMOR, Horbach MA. Frutification and germination ecology of Citharexylum myrianthum Cham (Verbenaceae). J Biotec Biodivers, 2013; 4:207-215.

Antunes RMP, Lima EO, Pereira MSV, Camara CA, Arrudal TA, Catão RMR, Barbosa TP, Nunes XP, Dias CS, Silva TMS. Atividade antimicrobiana "in vitro" e determinação da concentração inibitória mínina (CIM) de fitoconstituintes e produtos sintéticos sobre bactérias e fungos leveduriformes. Rev Bras Farmacog, 2006; 16:517-524.

Ayers A, Sneden AT. Caudatosides A-F: new iridoid glucosides from Citharexylum caudatum. J Nat Prod, 2002; 65:1621-1626.

Balázs B, Tóth G, Duddeck H, Soliman HS. Iridoid and lignan glycosides from Citharexylum spinosum L. Nat Prod Res, 2006; 20:201205.

Barizão EO, Visentainer JV, Almeida VC, Ribeiro D, Chisté RC, Fernandes E. Citharexylum solanaceum fruit extracts: Profiles of phenolic compounds and carotenoids and their relation with ROS and RNS scavenging capacities. Food Res Int, 2016; 86:24-33.

Bébéar C, Robertson J. 1996. Molecular and diagnostic procedures in mycoplasmology. 2 ed. California, U.S.A.: Academic Press.

Bosse TS. Fitoterápicos no SUS. 2014. (Monography). Pósgraduação em Farmacologia, Universidade do Extremo Sul Catarinense UNESC.

CLSI. Methods for Dilution Antimicrobial Susceptibility Tests f or Bacteria That Grow Aerobically; Approved Standard - Ninth Edittion. CLSI document M97-A9. Wayne, PA: Clinical and Laboratory Standards Institute; 2012.

Deguchi T, Ito S, Yasuda M, Kondo H, Yamada Y, Nakane K, Mizutani K, Tsuchiya T, Yokoi S, Nakano M. Emergence of Mycoplasma genitalium with clinically significant fluoroquinolone resistance conferred by amino acid changes both in GyrA and ParC in Japan. J Infect Chemother, 2017; 23:648-650.

Eller SCWS, Feitosa VA, Arruda TA, Antunes RMP, Catão RMR. Avaliação antimicrobiana de extratos vegetais e possível interação farmacológica in vitro. Rev Ciênc Farm Bas Apl, 2015; 36:131-136.

Ganapaty S, Rao DV, Pannakal ST. A phenethyl bromo ester from Citharexylum fruticosum. Nat Prod Commun, 2010; 5:399-402.

Gao H, Liu Y, Li K, Wu T, Peng J, Jingó F. Hispidulin induces mitochondrial apoptosis in acute myeloid leukemia cells by targeting extracellular matrix metalloproteinase inducer. Am J Transl Res, 2016; 8:1115-1132.

Gobbo-Neto L, Lopes NP. Plantas medicinais: fatores de influência no conteúdo de metabólitos secundários. Quim Nova, 2007; 30:374-381.

Hamed ANE, Muhammad MHH, Khalil HE, Kamel MS. 2014. Biological studies of Citharexylum quadrangulare jacq. family Verbenaceae. Assiut Univ. 9th International Pharmaceutical Sciences Conference 2014. [ONLINE] Available at: https://www.researchgate.net/ publication/274376180_Assiut_Citharexylum_Bio $>$ Abstract_form.

Holetz FB, Penssini GL, Sanches NR, Cortez DAG, Nakamura C, Dias-Filho BP. Screening of some plants used in the Brazilian folk medicine for the treatment of infectious diseases. Mem Inst Oswaldo Cruz, 2002; 97:1027-1031.

Intisar A, Zhang L, Luo H, Kiazolu JB, Zhang R, Zhang W. Anticancer constituents and cytotoxic activity of methanol-water extract of Polygonum bistorta L. Afr J Tradit Complement Altern Med, 2012; 10:5359.

Ipe - Instituto de Pesquisas Ecológicas. Citharexylum myrianthum Cham. 2016. [ONLINE] Available at: http://www.ipe.org.br/.

Johnstone RW, Ruefli AA, Lowe SW. Apoptosis: a link between cancer genetics and chemotherapy. Cell, 2002; 108:153-64.

Khan MR, Siddique F. Antioxidant effects of Citharexylum spinosum in $\mathrm{CCl}_{4}$ induced nephrotoxicity in rat. Exp Toxicol Pathol, 2012; 64:349-355

Mar A, Pripdeevech P. Chemical composition and antibacterial activity of essential oil and extracts of Citharexylum spinosum flowers from Thailand. Nat Prod Commun, 2014; 9:707-10.

Michelin DC, Moreschi PE, Lima AC, Nascimento GGF, Paganelli MO, Chaud MV. Avaliação da atividade antimicrobiana de extratos vegetais. Rev Bras Farmacogn, 2005; 15:316-320.

Mohammed MHH, Hamed ANES, Khalil HE, Kamel MS. Phytochemical and pharmacological studies of Citharexylum quadrangulare Jacq. Leaves. J Med Plants Res, 2016; 10(18).

Muraiana IA, Picard J, Eloff JN. Development of a reproducible method to determine minimum inhibitory concentration (MIC) of plant extract against a slow-growing mycoplasmas organism. Phytomed, 2009; $16: 262-264$

Murray PR, Baron EJ. 2007. Manual of Clinical Microbiology. 9 ed. Washington, U.S.A.: ASM Press.

Newman DJ, Cragg GM. Natural products as sources of new drugs from 1981 to 2014. J Nat Prod, 2016; 79:629-661.

Rasheeda K, Bharathy H, Nishad Fathima N. Vanillic acid and syringic acid: Exceptionally robust aromatic moieties for inhibiting in vitro self-assembly of type I collagen. Int J Biol Macromol, 2018; 113:952-960.

Rocca-de-Andrade MA. Biologia da polinização da espécie arbórea Citharexylum myrianthum Cham. (Verbenaceae), polinizadores e utilização do recurso floral pelos visitantes. 2001. Thesis (Master's Degree) - Instituto de Biologia, Programa de Pós-Graduação em Ecologia, Universidade Estadual de Campinas - UNICAMP, Campinas.

Rosa LS, Monteiro MC, Silva NJ, Teodoro AJ. Antioxidant activity of phenolic acids and cytotoxic effect in human adenocarcinoma cells. 11 SLACA, 2015; 2.

Saidi I, Waffo-Téguo P, Ayeb-Zakhama AEL, Harzallah-Skhiri F, Marchal A, Ben Jannet H. Phytochemical study of the trunk bark of Citharexylum spinosum L. growing in Tunisia: Isolation and structure elucidation of iridoid glycosides. Phytochem, 2018; 146:47-55.

Seoane S, Montero JC, Ocaña A, Pandiella A. Effect of multikinase inhibitors on caspase-independent cell death and DNA damage in HER2-overxpressing breast cancer cells. J Natl Cancer Inst, 2010; 102:1432-1446. 
Shulz M, Borges GSC, Gonzaga LV, Seraglio SKT, Olivo IS, Azevedo MS, Nehring P, Gois JS, Almeida TS, Vitali L, Spudeit DA, Micke GA, Borges DLG, Fett R. Chemical composition, bioactive compounds and antioxidant capacity of juçara fruit (Euterpe edulis Martius) during ripening. Food Res International, 2015; 77:125-131.

Velleca W, Bird B, Forrester F. 1979. Laboratory diagnosis of Mycoplasma infections. Course 8226-C, U.S. Department of Health, Education and Welfare, Public Health Service, Centers for Disease Control, Atlanta, U.S.A.

Wang YG, Liu WP, He XS, Fei Z. Hispidulin enhances the antitumor effects of temozolomide in glioblastoma by activating AMPK. Cell Biochem Biophys, 2015; 71:701-706.

Yemip GP, Pagotto F, Bach S, Delaquis P. Effect of vanillin, ethyl vanillin, and vanillic acid on the growth and heat resistance of Cronobacter species. J Food Prot, 2011; 74:2062-2069.
Yu J, Liu H, Lei J, Tan W, Hu X, Zou G. Antitumor activity of chloroform fraction of Scutellaria barbata and its active constituents. Phytother Res, 2007; 21:817-22.

\section{How to cite this article:}

Tenfen A, Cechinel-Zanchett CC, Dalmagro AP, Zimath P, Boeder AM, Santos GMD, Campos A, Sibert DA, Micke G, Vitali L, de Córdova CMM, Bella-Cruz A, Niero R, CechinelFilho V. Biological potential of Citharexylum myrianthum Cham. leaves in vitro and phenolic profile by HPLC-ESI-MS/ MS. J App Pharm Sci, 2018; 8(09): 074-080. 